\title{
Hurufilikte Ebced Hesabının Kullanımına Dair Bir Risale
}

\section{A Pamphlet on the Use of abjad Calculations in Hurufism}

\begin{abstract}
Özer ŞENÖDEYİĊ ${ }^{*}$ Ahmet AKDAĞ $\breve{G}^{* *}$

Öz: İnsanoğlunun harfler ve sayılara gizli anlamlar yüklemesi oldukça eski devirlere uzanan bir alışkanlıktır. Bazı âlimlerin harflere gizli anlamlar yüklediği ve var oluşu bu şekilde açıklamaya çalıştığı görülebilir. Ancak bunlar arasında en dikkat çekicisi Hurufilik adıyla anılan sistemi kuran Fazlullah-1 Esterâbâdî’nin tevilleridir. Fazlullah-1 Esterâbâdî, Arap alfabesindeki yirmi sekiz ve Fars alfabesindeki otuz iki harfi; insan yüzündeki tüylerle, el parmaklarındaki eklemlerle; hazarda, seferde ve Cuma günü kı11nan namazlarla ilişkilendirmiş ve böylece kendine mahsus bir Kur'ân yorumlama yöntemi geliştirmiştir. Belirli sayıların insan yüzündeki tüylerle olan münasebetinden, Kur'ân'da bazı surelerin başında bulunan ayet değerindeki harflerden, her şeyi ortadan ikiye ayırdığı farz edilen istiva hattından ve tamamıyla öznel çağrışımlardan istifade eden Hurufiler, Türk kültür ve inanç tarihini olduğu kadar edebiyatını da derinden etkileyen bir sistem geliştirmişlerdir. Hurufîler, bu materyallerin yanı sıra harflerin sahip olduğu sayı değerinden de yararlanmışlardır. Ancak Hurufilerin ebcede bakışlarını konu alan müstakil bir eser şimdiye kadar tespit edilememiştir. Genellikle tarih düşürme, fal bakma, büyü, muska ve benzeri uygulamalarda kendisine başvurulan ebcedi Hurufiler, inançlarını destekleyecek bir kanıt olarak değerlendirmişlerdir. Bu çalışmada, Hurufilikte ebcedin yerini ve kullanım sahasını izah eden bir risale neşredilecek, bu sayede Hurufiliğin kendine özgü tevillerinin daha iyi anlaşılabilmesine olanak sağlanacaktır.
\end{abstract}

Anahtar sözcükler: Hurufilik, ebced, sayı mistisizmi, Fazlullah-1 Esterâbâdî, tevil

Abstract: The attribution of hidden meanings to letters and numbers has been a practice of humankind from the dawn of literacy onwards. One can observe some scholars attributing hidden meanings to letters and trying to explain existence in this way. Most remarkable among them are the interpretations in the $14^{\text {th }}$ century by Fazlullah-1 Esterâbâdî, the founder of the system known as Hurufism. Fazlullah correlated the 28 letters of the Arabic alphabet and the 32 letters of Persian with hair on human face, joints of fingers, peacetime, voyage and Friday prayers and he developed his peculiar way of interpreting the Kur'an. Hurufis, benefiting from the relation between certain numbers and features of the human beings' face; from the letters given in the beginning of the verses of most sections of Qur'an; from the lines believed to divide everything into two and from completely subjective connotations developed a system deeply influencing Turkish literature and culture and the history of belief. Hurufi's also occasionally employed abjad calculations. However, to date we have found no substantive study concerning the Hurufis' approach in respect to abjad, which was usually employed to record dates, for fortune telling, for witchcraft and in the writing of amulets, was a resource for the Hurufis. In this work, a pamphlet explaining the uses of abjad in Hurufism is issued to permit a better understanding of Hurufis' peculiar interpretations.

Keywords: Hurufism, abjad, number mysticism, Fazlullah-1 Esterâbâdî, interpretation

\footnotetext{
* Doç. Dr., Karadeniz Teknik Üni., Edebiyat Fak., Türk Dili ve Edebiyatı Böl., Trabzon, ozersenodeyici@gmail.com

**Arş. Gör., Karadeniz Teknik Üni., Edebiyat Fak., Türk Dili ve Edebiyatı Böl., Trabzon, angelir.02@hotmail.com
} 


\section{Giriş}

Arap harflerinin sekiz anlamsız sözcük meydana getirecek biçimde istiflenmiş biçimine ebced düzeni adı verilir. $\mathrm{Bu}$ düzende her bir harfin bir sayısal karşılığı vardır. Meydana getirilen anlamsız sözcüklerin ilkinin ebced (ابجد) olması, elde edilen istifin bu isimle anılmasını sağlamıştır. Bu dizilime abcad, ebiced, ebicad, abucad da denmektedir (Yakıt, 2010, 25). Harflerin anlamsız da olsa telaffuz edilebilir sözcükler biçiminde kodlanması, onların ezberde tutulmasını kolaylaştırmıştır. Ebced sistemini oluşturan sekiz sözcük şunlardır:

$$
\begin{aligned}
& \text { ebced (ابجد) sa'fas (سعفص) } \\
& \text { hevvez (هوّز) karaşet (قرشت) }
\end{aligned}
$$

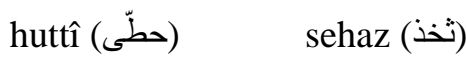

$$
\begin{aligned}
& \text { kelemen (ضظن) zazağ) }
\end{aligned}
$$

Her bir harfin bu hesaba göre sayı değeri aşağıdaki gibidir (Tabloda verilen sayı değerleri küçük ebced (asıl ebced, cümel-i sagîr) denilen usule göredir. En yaygın ebced usulü bu olmakla birlikte en küçük ebced hesabı (cümel-i asgar), büyük ebced hesabı (cümel-i kebîr) ve en büyük ebced hesabı (cümel-i ekber) gibi farklı usuller de vardır. Bunların her birinde harflere verilen sayı değeri değişir):

\begin{tabular}{|c|c|c|}
\hline Arapça Harfler & Türkçe Okunuşları & Sayısal Değerleri \\
\hline 1 & Elif & 1 \\
\hline ب & $\mathrm{Be}$ & 2 \\
\hline ج & Cim & 3 \\
\hline$د$ & Dal & 4 \\
\hline 0 & $\mathrm{He}$ & 5 \\
\hline 9 & Vav & 6 \\
\hline j & Ze & 7 \\
\hline$\tau$ & $\mathrm{Ha}$ & 8 \\
\hline$b$ & $\mathrm{~T}_{1}$ & 9 \\
\hline$\checkmark$ & Ye & 10 \\
\hline ك & Kef & 20 \\
\hline J & Lam & 30 \\
\hline b & Mim & 40 \\
\hline ن & Nun & 50 \\
\hline س - س & Sin & 60 \\
\hline$\varepsilon$ & Ayn & 70 \\
\hline ف & $\mathrm{Fe}$ & 80 \\
\hline ص & Sad & 90 \\
\hline ق & Kaf & 100 \\
\hline J & $\mathrm{Re}$ & 200 \\
\hline ش & Şı & 300 \\
\hline$ت$ & $\mathrm{Te}$ & 400 \\
\hline ڤ & $\mathrm{Se}$ & 500 \\
\hline$\dot{\tau}$ & $\mathrm{H}_{1}$ & 600 \\
\hline$\dot{j}$ & Zel & 700 \\
\hline ض & Dad & 800 \\
\hline b & $\mathrm{Z}_{1}$ & 900 \\
\hline$\dot{\varepsilon}$ & Gayn & 1000 \\
\hline
\end{tabular}

Tablo 1. Ebced Hesabına Göre Harflerin Sayı Değerleri 
Ebcedin en yaygın kullanım alanı, estetik bir hüviyet kazanmış olan "tarih düşürme"dir. Tarih düşürme yoluyla şairler, önemli gördükleri olayların senesini kayıt altına almışlardır. Buna Râşid'e ait, Sultan Abdülmecit'in Tırnova'ya gelişine düşürülen tarih, örnek olarak verilebilir:

Geldi bâ-ilhâm Râşid kalbe târîhin dedim

Tirnovî’ye bastı ‘izzetle kadem Sultân Mecîd

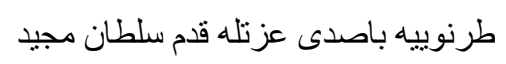

(H. 1262 / M. 1845)

\section{$9+200+50+6+10+10+5+2+1+90+4+10+70+7+400+30+5+100+4+40+60+30+9+1+50+$ $40+3+10+4=1260$}

Şair ilk mısradaki "geldi bâ" ifadesiyle bu toplama be (ب) harfinin sayı değeri olan 2'nin de eklenmesi gerektiğini söylemektedir. Böylece Sultan Abdülmecîd'in Tırnova'ya geldiği 1262 tarihini ebced hesab1 yoluyla vermektedir (Şenödeyici, \& Akdağ, 2013, 59).

Ebced hesabı yalnızca tarih düşürmede değil, cifr ve vefk ilimlerinde, büyü, tılsım ve muskalarda, burçları öğrenmede, define aramada, tasavvufî yorumlarda, zikr sayılarının belirlenmesinde, Kur'ân tefsirlerinde, Kadir Gecesi'nin tespitinde, musikîde, matematikte, günlük ihtiyaçlar vb. uygulamalarda da kullanılmıştır (Karabey, 1983; Yakıt, 2010, 58-66).

Ebcedin ilk olarak kim tarafından kullanıldığı bilinmemektedir. Kültürel hayat içinde kendisine önemli bir yer edinen ebcedin icadı, efsane kabilinden bazı rivayetlere konu olmuştur. Bunlardan birine göre söz konusu tasnifteki ilk altı sözcük (ebced, hevvez, huttî, kelemen, sa'fas, karaşet) Medyen ülkesinin altı şahının adıydı. Eyke halkının kırıldığı gün, onlar da yok oldular. Bunların adlarında kullanılmayan harflerle ise sehaz ve zazağ sözcükleri oluşturularak tüm Arap harflerini kapsayan bir sistem vücuda getirilmiştir (Mercanlıgil, 1960, 18-19). İlgili tasnifteki ilk altı sözcük hakkında farklı rivayetler de bulunmaktadır. Buna göre ilk altı sözcük, altı şeytanın adı, haftanın günleri, ilahî isimlerin altı anahtarı, altı emir ve yasak, altı nasihat gibi kavramlara karş1ık gelmektedir (Ebceddeki anlamsız sözcüklerin sekizini birden kapsayan bazı açılkamalar da mevcuttur. Örneğin bu sekiz sözcü̈ğün birer filozof adı olduğu yahut Iran hükümdarı Sâbûr'un sekiz çocuğuna işaret ettiği söylenmiştir (Yakıt, 2010, 26-31). Bazı kaynaklarda ise sekiz sözcüğün her birinin, Adem'in cennetten kovulması ve affedilmesi arasındaki devrelere işaret ettiği belirtilmiştir. Bu düşünceyi konu alan bir risalede ebced ve hevvez sözcükleri şöyle açıklanmıştır: "Ebced: Âdem aleyhisselâm günâh işledi. Nitekim Hak Te`âlâ

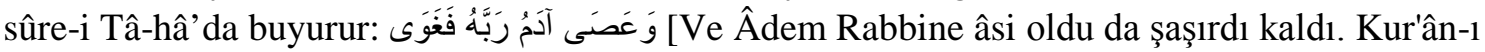
Kerîm,Tâ-hâ: 121] Hevvez: Gökten yere indi. Nitekim Hak Te‘âlâ sûre-i Bakara’da buyurur: Biz de "Kiminiz kiminize düşman olarak inin, sizin için yeryüzünde belli bir vakte kadar bir yerleşim ve meta vardır" dedik. Kur'ân-1 Kerîm, Bakara: 36] Bundan ma'lûm oldu ki kişi günâh sebebiyle a'lâ dereceden ednâ dereceye iner imiş. İmdi ey âdemoğlu! Âdem aleyhisselâm ahvâlinden ibret alıp günâhtan sakın ki Âdem Peygamber günâh sebebiyle cennetten yere indi. Ammâ 'acebdir sen çok günâhlar ile tevbe etmeyip cennete girmek istersin ve çünkim Âdem aleyhisselâm günâh sebebiyle makâmdan düştü, Hak Te'âlâ cânibine yüz tutup tevfîk ve hidâyet edip tevbe tarîkin öğrenip tevbe

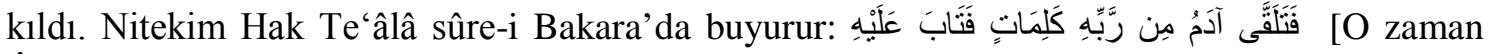
Âdem, Rabbinden birtakım kelimeler aldı (ve onlarla yalvardı, tevbe etti), bunun üzerine (Rabbi) tevbesini kabul etti. Kur'ân-1 Kerîm, Bakara: 37] ve sûre-i Tâ-hâ'da buyurur: نُمَّ اجَتَبَاهُ رَبَبُْ

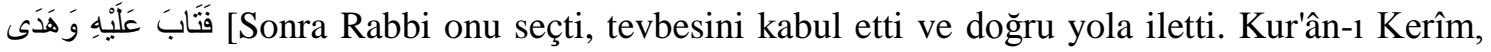
Tâ-hâ: 122]” (06 Mil Yz B 489/40). 
Tarihte, insanoğlunun sayılara ve harflere batınî mânâlar yüklemesine dair örnek, oldukça fazladır. Harfçilik, tarihsel süreçte farklı biçimler ve adlar altında pek çok kimsenin zihnini meşgul etmiştir. Tıpkı simya ve sihir telakkileri gibi huruf ilmi de gelecekten haber alma, şartlara müdahale ederek sonucu değiştirme amaçlarına yönelik olarak eskiden beri kullanılagelmiştir. Nitekim "gizli anlamlar içerdiği kabul edilen harflerin insana ve tabiata tesir ettiği inancına eski Mısır, Yakındoğu ve Hint uygarlıklarında, daha sonraları Yahudi, Hiristiyan ve İslam kültürlerinde rastlamak mümkündür. Hellen filozofları arasında da bu telakki zaman zaman kabul görmüşı̈̈r" (Aksu, 1998, 397). Mesela Pisagoras, âlemin ilk prensibinin, aralarında bir düzen ve uyum bulunan sayılar olabileceğini ileri sürmüştür. Ona göre, "eşya, duyulur hale gelmiş sayllardır. Bilimin amacı, her varlı̆̆ karşılayan sayıları bulmaktır. Örneğin akıl belli bir sayıdır, ruh belli bir sayıdır, adalet belli bir sayıdır. Evren, bir sayı uyumudur" (Hançerlioğlu, 1993, 76).

İslâm âleminde harfleri kullanarak varlığı ya da çeşitli gizemleri açıklamaya çalışan pek çok kişi zuhur etmiştir. Ebu Mansur İclî, Sehl bin Tüsterî, el-Hakîm et-Tirmizî, Ebû Abdullah Hüseyin bin Mansur Hallâc, el-Bûnî bunlardan bazılarıdır (Usluer, 2009, 109-111). Var oluşu anlamak ve anlatmak için harflere başvuran bir diğer isim Muhyiddin İbnü'l-Arabî' dir. Doğu'da okült ilimlerin revaç görmesinde önemli payı olan bu zat, harfler ve sırlar arasında kurduğu münasebeti bu konuya tahsis ettiği müstakil eserlerde işlemiştir. Teveccühâtü'l-Hurûf, Kitâbu'lElif, Kitâbu'l-Mîm ve'l-Vâv ve'n-Nûn, Kitâbu'l-Yâ, Kitâbu'l-Cîm, el-Mebâdî ve'l-Gâyât fî mâ Tehvî aleyhî Hurûfu Mu'cem fî'l-'Acâ'ib ve'l-Âyât bunlara örnek olarak anılabilir (Küçük, \& Saraç, 2009, 698). İbnü’l-Arabî, harflerle ilgili düşüncelerini iki zemin üzerine oturtur. Bunlardan ilkinde, insanların harfler vasıtasıyla konuşmasını Tanrı'nın varlığı yaratmasına intikal ettirir ve iki durum arasında bir ilişki kurar. İkincisinde ise elif ve be harflerine odaklanır, elifin yaratıcıyı be'nin ise yaratılanı ve yaratılışı simgelediği üzerinde durur (Demirli, 2008, 229). Türk sufileri arasında da harf metafiziği olarak nitelenebilecek bu telakkilere meyledenler olmuştur. Bursalı İsmail Hakkı, bunlardan birisidir. O, yazmış olduğu Esrâru'l-Hurûf risalesinde harflerin mistik yorumuna yer verir. Örneğin risalede be ve te harfleri şu şekilde izah edilir: "Be: Bir bedr ki kemâl-i lutf u kereminden şu'ûnât-l gaybiyyeyi suver-i 'ilmiyyede izhâr edip ağyâr-ı sâniye kılmışıtır ki ona zull-ı ilâhî derler ve bu ma "nâ be-vech-i esmâ-i zâtiyyeden nâşîdir. Nikâh-ı evvel mertebesidir. Te: Te 'kîddir ki mütekellim olduğu cihetten âyât-ı tekvîniyyeyi tenzîl etmiştir ki mertebe-i 'amâ-i kevnîde vücûd bulan ervâh-l 'âliyyedir ki 'akl-ı evvel onların re'îsidir. Bu mertebe ta'ayyün 'ilmînin nâlîsi ya'nî tâbi'i olmakla iki nokta ile mu'allem oldu. Zîrâ 'âlî sâfile nüzûl etse sırrı ile nüzûl eder" (Süleymaniye Kütüphanesi, Hacı Mahmud Ef. Yaz. / 2537, vr. 22b-23a).

İslâm coğrafyasında harflere duyulan ilgi, birbirinden farklı telakkilerin vücuda gelmesini sağlamıştır. Bilhassa mutasavvıflar ayetleri, hadisleri ve Allah'ın isimlerini; harfler ve sayılar arasında kurulan münasebetle izah etmeye çalışmışlardır. Bunun yanı sıra gaybdan haber alabilmek için de aynı materyallere başvurulmuştur. Ebced, harfler ve sayılar arasında kurulan farazî bir özdeşliğe dayansa da, ona başvuranlar tarafindan muteber bir araç sayılmıştır. "Kâinatta hakayık-ı eşyaya taalluk eden birtakım esrarı ihtiva ettiğine inanılan harfler, 'ilm-i esrâr-ı hurûf' veya 'ilm-i sagîr de denilen simya ilminin doğuşuna sebep olmuş ve bu vadide yüzlerce ilm-i huruf kitabı kaleme alınmıştır. Harflerin adedî olarak değerlendirilmesi olan ve İlâm âleminde değişik ve çok sanatlı şekillerde yayılmış bulunan ebced hesabı da, kullanım sahasının genişliği ve tesirleriyle, harflerden doğan ilimlerin en mühimlerinden biridir" (Ceylan, 1997, 142-143).

Ebced hesabının verdiği imkânlar kutsal kaynakların farklı açılardan işlenebilmesine imkân sağlamıştır. Ebced hesabının metinlere uygulanması, ebcede dayandırılarak sırların ifşasının 
mümkün olduğunun iddia edilmesi, günümüzde de rağbet gören bir anlayıştır. Bu hesabın metinlere uygulanması yoluyla çeşitli veriler elde etmek kolaydır. Söz konusu bir kutsal kitap olduğunda ise, insanların inançlarını herhangi bir yönde destekleyecek, niyete uygun sonuçlar bulmak son derece kolaydır. Ebcedin özelliğini bilmeyen biri için, veriler gayet çarpıcı ve inandırıcı olabilir.

Varlığın esasını harfler ve sayılar üzerinden izah etmeye çalışan Hurufilik inancında da ebced hesabının sağladığı imkânlardan istifade edilmiştir. Hurufiliğin ebcede bakışını müstakil olarak işleyen herhangi bir kaynak şimdiye kadar tespit edilememiştir (Onlara göre her bir harf, dinî birtakım kavramlar ile insan vücudunun uzuvlar harflere teşbih edilir. Mesela, ayn'ın göze, mim'in ağza vs. benzemesi gibi. Gerçi bazı mutasavvif şairler bu kültürden etkilenerek bazı şiirler yazmışlardır, ama Hurufilik ile tasavvufi ve felsefi yorumların arasinda mahiyet farkı vardır. Açılamalar arasındaki nüanslar ve temel bazı hususiyetler, dikkat edilmezse karlştırllabilir. Öte yandan, ebced alfabe düzeninin Hurufilik cereyanıyla ilişsisine bugüne kadar yaptığımız araştırmalarda rastlamış değiliz, Yakıt, 2010, 33-34). Esterabatlı Fazlullah tarafından kurulan Hurufilik, İslâm dini akidelerini ve ibadetlerini harfler ve sayllar yoluyla izah etmeye çalışan bir sistemdir. Uzunca bir süre mezhep, tarikat ya da müstakil bir din olduğu yönünde çeşitli görüşler ileri sürülen bu sistemin, İslâmiyet dışında düşünülmesi imkânsızdır. Tüm yorumlarını İslâmî kaynaklar üzerinden geliştiren Fazlullah, sünnet ehlinin oldukça yadırgadığı kendine mahsus teviller ortaya koymuştur. Millî bir hassasiyet göstererek Arap alfabesindeki yirmi sekiz harf ile Fars alfabesindeki otuz iki harfi birbirine denk gören Fazlullah, öncelikle bu denklik üzerinde durur. Fars alfabesinde bulunup Arap alfabesinde bulunmayan dört harfe (ษ, ج tevillerinin ilk numunelerini verir. Lâmelifi oluşturan harfler ayrı ayrı yazıldığında ortaya altı

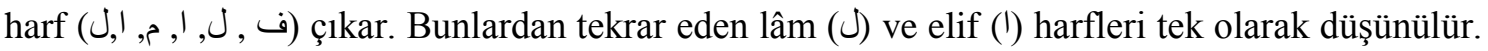
Böylece Fars alfabesinde bulunup Arap alfabesinde bulunmayan dört harf sorunu çözülmüş olur. Yirmi sekiz ve otuz iki rakamlarını, başta ibadetlerde arayıp bulan Hurufiler, harf-rakam kombinasyonlarının sağladığı imkânlarla İslâm'ın beş şartını izah ederler ve onların sırrına erdiklerini düşünürler (bk. Usluer, 2009). Sözgelimi Hurufilerin abdest hakkındaki yorumları, Ferişteoğlu'nun Hidâyetnâme'sinden hareketle şöyle özetlenebilir: "İnsanın gusul mahalli olan uzuvlarında; elinde, ayă̆ında ve yüzünde 28 ile 32 harf zahirdir. O uzuvlarl yıkamak gerektir. Bu şekilde baktığımda elimi, ayă̆ımı ve yüzümü 28 ile 32 ilahı̂ harf karşılığında bölünmüss buldum. İlahî hat ve yazlyı bu beş uzuvdan başka uzuvlarda zahir görmedim. Isşte bu nedenle 28 'e karşılık gelen bu beş uzvu ylkamak gerekir... Parmaklar ve eklemler hikmeti ile namaz sayısının hikmetine vakıf ve hâkim olasın. Şöyle ki her insanın elinin on dört eklemi vardır; şöyle ki iki elin yirmi sekiz eklemi vardır. O yirmi sekiz ilahî harfe karşılıktır ve Kur'ân'ın aslıdır" (Şenödeyici, 2009, 104).

Daha önceki herhangi bir harfçi telakkinin devamı ya da kolu olmayan Hurufilik, İran'dan ziyade Anadolu coğrafyasında kabul görmüş ve Türk inanç tarihinde önemli bir yer edinmiştir. Bu sistemin ebced hesabı hakkındaki yorumlarını konu alan "Tefsîr-i Ebced" adlı eser, Hurufilerin bu husustaki düşüncelerini özetlemektedir.

Tefsîr-i Ebced, klâsik bir Hurufi metni olarak soru-cevap üslûbu ile kaleme alınmıştır. Müellif, muhataplarına "ey tâlib-i âşık-ı esrâr-ı ilâĥे" gibi nidalarla seslenmektedir. Sorular ebcedle ilgili olup Hurufilerin ebced hesabından nasıl yararlandıklarını açıklamaktadır. Müellif, öncelikle ebcedin muteber bir kaynak olduğunu vurgulamak için Hazreti Peygamber'in bu hesaba itibar ettiğine işaret eden bir anekdotla giriş yapar. Burada bir Yahudi'nin Hazreti Peygamber’e “Senin ümmetinin ömrü yetmiş bir ylldır. Çünkü sana elif, lâm, mim harfleri geldi. 
Bunların sayı değeri yetmiş birdir" mealinde bir iddiada bulunduğuna yer verilir. Bunun üzerine Hazreti Peygamber, kendisine daha sonra elif, lâm, mim, sad harflerinin de gönderildiğini söyleyerek Yahudi'nin, hesabında yanlışlık yaptığını belirtir. Anekdotun vermek istediği mesaj, ebcedin Peygamber tarafindan da kabul gördüğ̈̈ ve surelerin başında gelen müstakil harflerin (huruf-1 mukattaa) gizli anlamlar içerdiğidir. Eserde muhatap alınan kimsenin sorduğu sualler şunlardır: "Tefsîr-i ebced nedir ve kaç türlüdür? Harfler kaç adettir ve nasıl hesaplanırlar? Harflerin eczası nedir ve nerede hesaba katılır? Beş vakit namaz harflere nasıl karşllı gelir? Hesâb-ı cümel nedir ve nerede kullanılır? Bu hesapla ne hesaplanır? Hesâb-ı kebîr nerede kullanılır? Harflerin sayıları, eczası, noktaları hesâb-ı cümelde ve hesâb-ı kebîrde nasıl hesaplanır? Be harfi nasıl insan vücudunun aslı olur? Hazarda, seferde ve Cuma günündeki namazların esrarını be harfinde nasıl bulabiliriz? Hû kelimesi nedir? Allah bütün azalardan münezzeh ise, Allah 'in yüzü, Allah'ın eli ve Allah' 'n parmaklarl ne ifade eder? Yedullah nedir? Parmaklar nedir?" Bu soruların cevapları verilirken kimi zaman ebcede başvurulmuştur.

Müellif, Hurufilerin sayılardan dört şekilde istifade ettiğini belirtmektedir. Bunlar;

1. Harflerin sayıs1,

2. Harflerin eczası (Harflerden istifade edilirken kimi zaman Hurufiler, bir harfi onun söylenişindeki harf sayısına denk olarak düşünürler. Örneğin elif (') harfinin ismi yazıldığında üç harf ortaya çıkar (', ف, U, İşte bunlar elif harfinin eczasıdır).

3. Hesâb-1 cümel (küçük ebced)

4. Hesâb-1 kebîrdir (büyük ebced).

Müellif bu sistemlerin nasıl kullanıldığını da birer örnekle açıklar:

Harflerin sayısı: Kef, he, ye, 'ayn, sad (Meryem Suresi'nin başında yer alan müstakil harflerdir) harfleri beş tanedir. Bunlar beş vakit namaza karşılık gelirler.

Harflerin eczası: Beş vakit namaz elif ve bâ harflerinin eczasıdır. Elif (') ve bâ (ب), kendilerini oluşturan harfler ayrı ayrı yazılmak suretiyle toplanırsa, ortaya beş harf çıkar $(1\rfloor, 4$, ). İşte bu beş harf, beş vakit namaza karşılık gelir.

Hesâb-ı cümel: Kur'ân'da Tâ Hâ suresi bulunmaktadır. Bu surenin adı ve ilk ayeti olan tı (b) ve he (॰) harflerinin küçük ebcede göre karşılığı on dörttür. Bu da on dört muhkemat harfine, aynı zamanda insan yüzündeki on dört ilahi hatta karşıl1k gelir.

Hesâb-1 kebîr: Küçük ebcede göre be harfi ikidir. Büyük ebcede göre ise on ikidir. Bu, on iki rekât işrak namazı ve insan yüzündeki on iki ilahi hat karşılığındadır.

Metinde harflerin sayısı, eczası ve noktaları ile ebced arasında münasebet kurulmuştur. Şöyle ki, bütün varlık "kün (كن)" emri ile yaratılmıştır. Küçük ebcede göre kâf (ك) ve nun (ن) harflerinin sayı değeri yetmiş eder. Buna, sözcüğü oluşturan iki harf de eklenirse yetmiş iki sayısı çıkar. Bu da Arap harflerinin okunuşlarında ortaya çıkan (eczâ) yetmiş iki harfe karşılık gelir. Bu sayıya nun (ن) harfindeki nokta da eklenirse, yetmiş üç sayısı elde edilir. Bu sayı ise, Hazreti Muhammet'in bir hadisinde işaret ettiği yetmiş üç firkaya karşılık gelmektedir.

Be harfinin, hazar, sefer ve Cuma namazlarına mukabil olduğu, metinde şöyle izah edilir: Bî (ب), büyük ebcede göre on ikidir. Bu okunuşu veren iki harf be (ب) ve ye (ب) eklenirse on dört olur. Bu harflerde bulunan üç nokta da ilave edilirse on yedi sayısına ulaşılır. Bu, hazarda kılınan on yedi rekât namaza karşılık gelir. Bî (ب), on ikidir. "Allah dilediği şeyi siler (Ra'd/39)" ayetinin delaletiyle on ikiden bir çıkarılırsa geriye on bir kalır. Bu da sefer zamanında kılınan rekât sayısıdır. Bî (بي), on ikidir. Kendisini meydana getiren harflerin üç noktası da hesaba katılırsa on beş olur. Bu da Cuma günü kılınan on beş rekât namaza karşılık gelir. 
"Hû" sözcügünün sırlarını izah ederken de ebcede dayanan bir tevil geliştirilmiş̧ir. Hî (هي) ve vâv (واو) harflerinin okunuşunda beş harf bulunur (o, s, g, I, و). Ye (ي) harfindeki iki nokta da eklenirse yedi sayısına ulaşılır. Bu, Havva'nın yüzündeki yedi ilahi hatta (ümmî hatlar) karşılık gelir. He (॰) harfi küçük ebcede göre beştir, vav (و) harfi ise altıdır. Íkisinin toplamı on bir eder. $\mathrm{Bu}$ sayının üstüne, sözcügü oluşturan iki harf ve sözcügün kendisi de eklendiğinde on dört sayısına ulaşı1ır. Bu da on dört ilahî hatta ve Tâ Hâ harflerinin küçük ebceddeki değerine işaret eder. Ayrıca on dört muhkemat harfine de ulaşmak mümkündür. "Hû (هو)"yu oluşturan hî (هي) ve vâv (واو) harflerinin eczası küçük ebcede (Metinde bu karşılığın büyük ebcede göre olduğu söylenmiştir) göre yirmi sekiz eder. Bu da yirmi sekiz Arap harfi mukabilindedir. Hî (هي) iki harften vücuda gelir, vâv (واو) da tekrar eden iki vav harfi bir kabul edildiğinde iki harften vücuda gelir. Ortaya çıkan bu dört harf, yirmi sekize ilave edildiğinde Fars alfabesindeki harf sayısı olan otuz iki elde edilir.

Metinde son olarak "vechullâh, yedullâh, esâbi'ü'r-Rahmân" kavramları üzerinde durulmaktadır. "Vech (وجه)" sözcügünü oluşturan vav (و), cim (ج) ve he (o) harflerinin küçük ebcede göre karş1lığ1 on dörttür. Bu sayı insan yüzündeki on dört ilahî hat hizasındadır. "Yed (يد)" sözcügünü oluşturan ye (ى) ve dal (د) harflerinin küçük ebceddeki değerleri de on dört eder. Esâbi' sözcügünü oluşturan elif ('), sad (ص), elif ('), be (ب), 'ayn (ع) harflerinin eczasında on dört harf bulunur. Böylece yine on dört ilahî hatta ulaşı1ır. Ayrıca bir elin parmaklarındaki eklem sayısı da on dörttür.

\section{Sonuç}

Ebcedin, Hurufilikteki yeri ve kullanımına dair ipuçları veren bu eser, Fazlullah'ın kendine has tevillerinin usulü hakkında önemli ipuçları vermektedir. Elde etmek istedikleri rakama ulaşmak için harflerin eczası, inbisatı ve noktalarının sayısını kullanmaktan çekinmeyen Hurufiler, yeri geldiğinde ebcedin imkânlarından da yararlanmışlardır. Kimi zaman insan aklına sığmayan bağdaşımlar kuran Hurufiler, kimi zaman da insanı hayrette bırakacak tespitler yapmışlardır. Savundukları tevillere sonuna kadar iman eden müritler sayesinde bu akım, İran sınırlarını aşıp Anadolu'ya ve oradan Rumeli'ye kadar yayılma imkânı bulmuştur. Söz konusu inancın daha iyi anlaşılabilmesi ve tevil usulünün daha iyi kavranabilmesi için kaleme alındığı anlaşılan ebced risalesi, Hurufiliğin bir yönüne daha 1şık tutmaktadır.

\section{Metin}

Eser, Milli Kütüphane Yazmaları 06 Mil Yz A 1688/5 numarada (17b-22a) "Tefsir-i Ebced" başlığıyla kayıtlıdır. Ta'lik yazıyla, samanlı kâğıda, her sayfası 15 satır olacak şekilde yazılmıştır. Eserin dış ve iç ölçüleri 168x115-118x68 mm'dir. Kapakları ciltten ayrı, mıklebli, sırtı ve sertabı bordo meşin, desenli kâğıt kaplı, mukavva ciltlidir. Söz başları ve cetvelleri kırmızı mürekkeple yazılmıştır.

Eserin metni transkripsiyonlu olarak aktarılırken Arapça ibareler aynen aktarılmış ve bunların manaları köşeli parantez içinde verilmiştir. Düzeltilmesi gereken bazı hesaplamalar ve sayı değerleri, metinde düzeltilmiş ve yapılan değişiklik belirtilmiştir. Metinde rakamla yazılan sayılar rakamla, yazıyla gösterilen sayılar yazıyla aktarılmıştır. Hurufiler ünsüzleri seslendirirken "ī" ünlüsünü kullandıklarından, bu metinde de vurgulanmamış olsa da bütün ünsüzler "ī” ünlüsü ile telaffuz edilmiştir. 19a varağının dokuzuncu satırında geçen "hatț-1 vechi ādem” ibaresi Hurufilere mahsus kısaltmalarla gösterilmiştir (Bu kısaltmalar için bk. Şenödeyici, 2009). Metinde harflere yüklenen bazı sayı değerleri, standart ebced hesabındaki değerlere uymamaktadır. Metinde verilen değerler değiştirilmemiştir. Büyük ebcedin standart

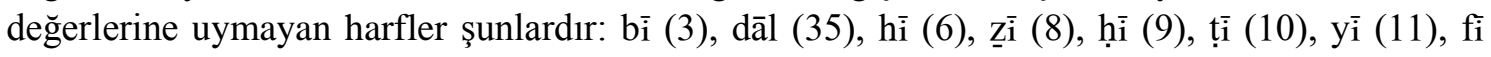




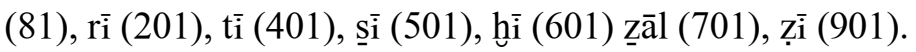

Metinde müstensihin dalgınlık veya dikkatsizliğinden olsa gerek tespit edilen bazı hatalar ve tutarsızlıklar şu şekilde düzeltilmiştir:

• 18a varağının on ikinci satırında geçen "ĥisāb-1 maĥall-i vāķi"' ibaresi " hisāb cümel" şeklinde,

- 21a varağının üçüncü satırında geçen "üç" kelimesi "dört" şeklinde,

- 21a varağının sekizinci satırında geçen "hū vardur" ibaresi "hî ve vāvdur" şeklinde,

- 21b varağının birinci satırında geçen "hî vardur" ibaresi "hî ve vāvdur" şeklinde,

- $\quad 21$ b varağının son satırında bulunan "on üçdür ola" ifadesi "on dörtdür" ve "on üçdür" ifadesi "on dört" şeklinde,

- 22a varağının üçüncü satırındaki "on üçdür" ifadesi "on dörtdür" ve aynı varağın altıncı satırındaki "on dörtdür" ifadesi ise "on dört" şeklinde düzeltilmiştir.

\section{[17b] Bismillāhirraḥmānirrahīm}

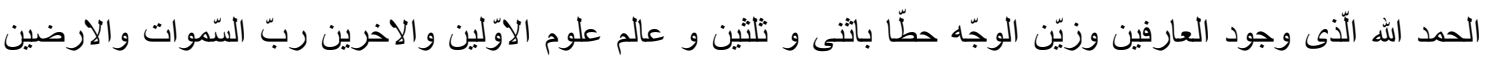

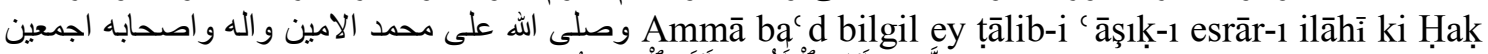

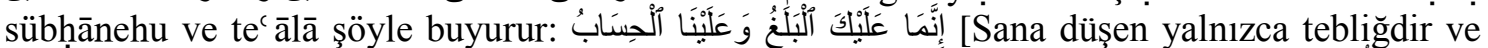

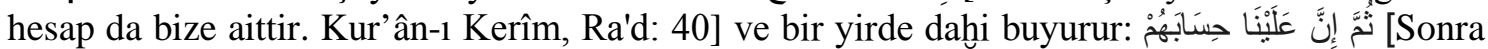
onları hesaba çekmek de elbette Bize aittir. Kur’ân-1 Kerîm, Gâşiye: 26] ve Hażret anuňçün şöyle buyurdı ki: ويل كلّ عالم لايعرف تفسير الابجد Ey țālib! Hażret-i Risālet 'aleyhisselām öginde bu tefsīr-i ebcede i'tibār-1 tām vardur. Şöyle ki Yahūdi dāniş-mendlerinden bir kişi Hażret-i Risālet'den su 'āl eyledi kim:

- Yā Muḥammed! Ḥażret-i Ḥaḳ'dan saňa elif lām mīm geldi. [18a] Resūl didi:

- Beli.

İmdi Yahūdī didi:

-Ben bilürem senün̆ ümmetün̆ 'ömri yitmiş bir sene ola. Şöyle ki elif birdür lām otuz mīm ḳırḳdur yitmiş bir ola. Ḥażret-i Risālet geldi didi:

- Dahi geldi anuň ardınca elif lām mīm șād.Yahūdī münfac il oldı, didi:

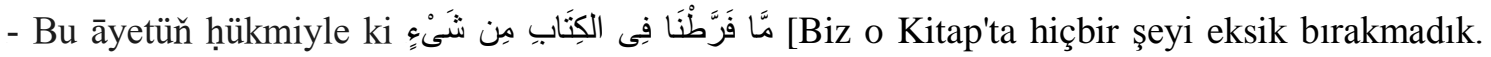
Kur'ân-1 Kerîm, En'âm: 38] Gerekd[ür] ki bu hịisāb cümle Ḳur'ān'da ola, vesselām.

Eger sā’il su'āl itse: “Tefsīir-i ebced nedür ve ḳaç dürlüdür?” Cevāb oldur ki: Ey țālib! Te’vīl 'ilminün̆ inbisāṭnda birḳaç vech iderler. Birisi oldur ki hurūf ' adedi maḥsūb ola. İkinci mahall-i vākị ol ki eczāsı hurūfuň maḥsūb. Üçünci mahall-i vāḳic hisāb-1 cümel. Dördünci hisāā-1 kebīr. Beşinci mahall-i vāḳic eczāsı noḳțaları hurūunuň mahsūb. Sā'il șorarsa: "Hurūfuň 'adedi nedür ve ne maḥalle vākịi ol 'adedi mạ̣sūb ola?’ Ey țālib-i [18b] șādıḳ! 'Aded-i hurūfu birdür. Ebced henūz ilā āḩirihi her bir ḥurūfi bir hisāa eyleyesin. Şöyle, eger bir kimse dise: "Beş vaḳt namāz ki vardur. Kur 'ān'da ve nenün̆ izāsındadur?” Cevāb: Kef, he, ye, 'ayn, șād beş vaḳt namāz mukābilindedür, vesselām.

Eger sā'il su'āl eylese: "Ḥurūfuň eczāsı nedür ve ne maḥalde maḥsūb ola?" Cevāb: Ey țālibi șādıḳ! Ḥurūfuň eczāsı budur: Elif, bī, cīm, dāl, ilā āhirihi. Elif üç ḥarf hisāàb idesin. Eger diye ki: "Bu beş vaḳt namāz ḥurūfuň izāsında nice biline?" Cevāb: Ey țālib! Elif bīāyetidür. Cümle ādemīlerün̆ beş ḥarfdür. Şöyle ki elif üç, bī iki ḥarfdür beş ola. Beş vaḳt namāz mukāāilindedür.

Eger sā'il dise: "Hisāb-1 cümel nedür ve ne mahalle mahsūb olur ola?" Cevāb: Ey țālib! Cümel budur 'azīzüm ki [19a] elif (1), bì (2), cīm (3), dāl (4), hì (5), vāv (6), zìi (7), ḥi (8), țì (9), 


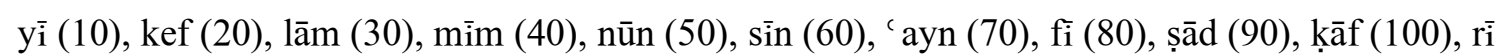

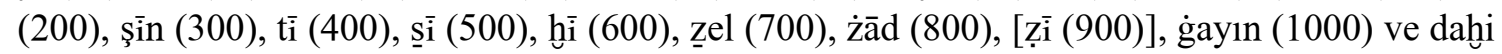
bir kişi dise: “İşbu hisābda ne maḥūu ola?”Cevāb: Ey tạlib-i ‘āşı̣! Ṭā hā ki Hażret-i Hạk te ālā hițāb eyledi, Muhammed Mușțafã 'aleyhisselām şöyle ki ți țoḳuz ve hỉ beş, on dört ola. 14 kelime-i muḥkemāt muḳābilinde ve on dört hutṭt-1 vech-i ādem muḳābilinde, vesselām.

Eger sā 'il dise ki: "Hisāb-1 kebīir ne maḥal maḥsūb ola?" Ey țālib! Hisāb-1 kebīir budur: Elif

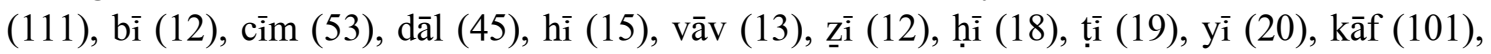
lām (71), mìm (90), nūn (106), sīn (120), ' ayn (130), fì (90), șād (95), ḳāf (181), rì (210), şīn (360), tì (410), și (510), hyi (610) [19b] zāal (731), żād (805), zại (910), ġayn (1060). Ey tạlib-i esrār-1 ilāhī! Ḥisāb-1 cümel-i șagīirde bī ikidür, hisāb-1 kebīrde on ikidür. Hażret-i Risālet 'aleyhisselām șalāt-1 işrāḳı on iki buyurdı. Bīmukāāilinde on iki huțūṭ̂t vech-i insān şöyle ki mūy-1 ser ü 'ārıż, be-hem muttașıl ḩatț-1 ilāhī dört kirpik ve dört hatț-1 ilāhī ve der-leb-i bālā dü, hațț-1 iśnā, țuṭakyek hatṭ̂-1 ilāhī ki 12 ola, bỉ ḥarfinüň izāsında vesselām.

Eger sā’il diye ki: “ Adedi ḥurūfuň ve eczāsı hurūfuň nuḳaṭları ḥurūfuň ve ḥisāb-1 cümelde ve hịāa-1 kebīrde ve ne maḥal maḥsūb ola?" Cevāb: Ey țālib! Hạk te ālā cemī' eşyāyı kelime-i

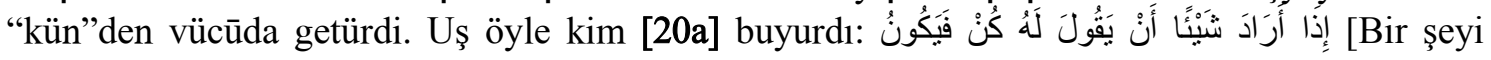
dilediği zaman 'Ol' der, o da hemen oluverir. Kur'ân-1 Kerîm, Yasin: 82] ve bu kelime-i "kün" 70 'dür. Hisāb-1 cümelde ve şöyle ki kef ve nūndur, yitmiş ola ve iki ' aded hurūf kendüsinüň ve yitmiş kelime-i ilāhī muḳābilinde ki aṣl-1 Kur ān-1 'Aẓ̄m'dür. Ve bir vech ile dahi kelime-i "kün" yitmiş üçdür. Kendü noḳțasıyla yitmiş üçfırḳa muḳābilinde ki Ḥażret-i Risālet buyurmışdur kim: مستفرق امتّى على ثلث و سبعين فرقه ]Ümmetim yetmiş üç firkaya ayrılacak. Tirmizî, İman: 18; İbnü Mâce, Fiten:17]

Sā’il su 'āl ide kim: "Bī key aṣl-1 vücūd-1 ādemdür?” Şöyle ki: Șāḥib-i te 'vīl 'azze faluhu buyurmışdur:

"Bī-i bismillāhirraḥmanirrahīm ādem-i hāà-īst"

Ey [țālib!] Bu rahīm-i șalāt ki üç nev'dür. Ḥażar, sefer ve cum`a ve bu üç nev' șalāt bī ḥarfinde nice bulmak olur? Cevāb: Ey 'āşık-1 șādık! Evvelā bī on yedidür. Şöyle ki bì hịsāb-1 kebīrde on ikidür ve iki eczāsı ḥurūfuň on dört [20b] ve üç noḳțası cem` ola: on yidi. On yidi rek at șalāt-1 ḥażar muḳābilinde ve dahi bì ki on ikidür. Bu āyetüň maḥkūmıla ki [Allah dilediği şeyi siler, yok eder. Kur'ân-1 Kerîm, Ra'd: 39] birin mạ̣v it, on bir ḳalur. On bir rek` at șalāt-1 sefer izāsında. Bī on ikidür. Ḥisāb-1 kebīrde ve üç noḳțası on beş olur. On beş rek $^{`}$ at cum` a izāsındadur.

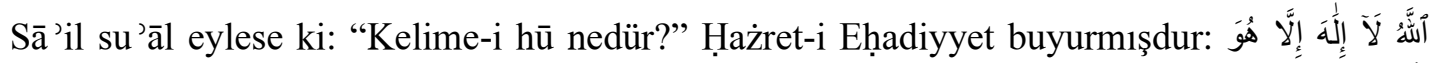

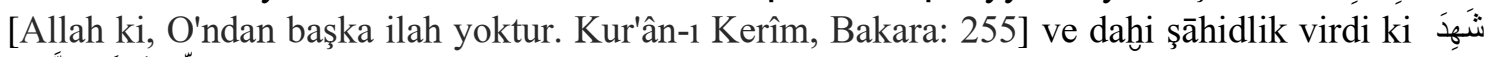
[Allah gerçekten kendisinden başka ilah olmadığına şahitlik etti. Kur'ân-1 Kerîm, Âl-i İmrân: 18] Ey țālib-i esrār-1 ilāhī! Evvelā hū yididür. Şöyle ki hī vāv $(0, \varsigma, 9,,, 9)$ beş ḥarfdür ve iki noḳtası yidi olur. Yidi saṭr-1 ilāhi ki Ḥavvā vechinde kendi ḳudret eliyle yazmışdur ve Ḥażret-i Risālet 'aleyhisselām buyurmışdur: انزل الهه القرآن على سبعة احرف [Allah Kur'ân'1 yedi harf üzere indirdi. İbn Hanbel, Müsned: III/7995; Taberi, Camiu'l-Beyan: I/25] [21a] Dīger hū on dörtdür. Şöyle ki hỉ hịsāb-1 cümelde 5 vāv 6'dur 11 ola. İki ' aded ḩarf bir şekl kendüsi on dört ola. Ḩațt-1Ṭā-hā'dur, Furḳān naḳşına beşāretdür. On dört huț̣utṭi ilāhī mukāābilindeki ādem vechinde kendü eliyle yazmışdur ve on dört kelime-i muḥkemāt aṣl-1 Furḳān-1 'Aẓīm'dür. Ya'nī Furḳān ta' rīf-i şereī atdur vesselām.

Ve dahi hū şöyle ki hī ve vāvdur. Ḥisāb-1 kebīrde bīst ü heşt ola. Bīst ü heşt kelime-i ilāhī 
muḳābilindeki Ḥażret-i Eḥadiyyet'den Ḥażret-i Risālet'[e] geldi ki Ḳur'ān'uň aṣlıdur. Ve daḩi şöyle ki hī vāv hịāâb-1 kebīrde bīst ü heştdür ve hīi iki ḥarfdür. Vāv dahi iki hạarfdür. Bī-tekrār قال sī ve dü ola ki sỉ ve dü kelime-i ādem mukābilinde aṣl-1 'ulūm-1 evvelīn, ahirīn mā-kān ve mā-yekūndur. Ve dahi hū otuz üçdür. Şöyle ki [21b] hū hī ve vāvdur. Hisāb-1 kebīide bīst ü heşt ola. Beş ḥurūf vardur, bīst ü heşt olur. Sì ve dü kelime-i ilāhī mukāābilinde. Bir ḥarf lāmelifdür. Ḥażret-i Risālet buyurmışdur lāmelif ḥarf-i vāḥiddür. Hażret-i Te'vīl-i Fażl ez-īn cihetdür. Ol cihet nāmeī-est ki bismillāhirraḥmanirraḥim hūdur. Taḳsīm-i vech-i Ādem ü Ḥavvā vesselām.

Sā’il dise ki: "Vechullāh, Yedullāh ve Eșābi ü’r-raḥmān ki Ḥażret fermūde vech remzest.

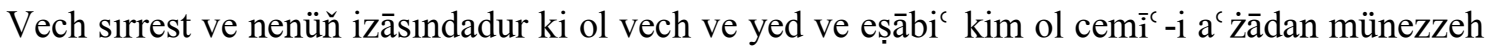
ve müberrādur?" Şöyle dirler, 'ilm ü ehāâdiyyet ve aḩbār-1 Resūlullāh'da cevāb oldur ki ey țālib-i esrār-1 ilāhī! Evvelā Vechullāh ki buyurdı. Vech hisāb-1 cümelde yüz otuz beşdür. Şöyle ki vāv cīm hì on dörtdür. On dört huṭ̂uț-1 ilāhī [22a] mukāāilindeki insān vechinde kendi eliyle yazılmışdur, vesselām.

"Yedullāh nedür?” Cevāb: Şöyle ki ey țâlib-i ilāhī! Bu dahi on dörtdür. Şöyle ki yī on, dāl dört on dört ola. On dört dest-i kelime-i ilāhỉ mukāāilinde ki aṣl-1 Ḳur’ān-1 'Aẓīm'dür.

Diseler ki "Eșābic nedür?" Ey țālib-i esrār-1 ilāhī! On dört ḥarf ki on dört mafșal mukāạilinde ve insānuň yedinde kendü eliyle maḥlūḳ itmişdür. Şöyle ki elif üç harfdür ve șād üç ḥarfdür ve bir elif daḩi üç ḥarfdür ve bỉ iki hạrfdür 'ayn daḩi üç ḥarfdür, 14 ola. On dört mafșal [mukāāilinde]. Nūrun 'alā nūrun buyurmışdur, vesselām. Temmet. 


\section{KAYNAKÇA}

Aksu, H. (1998). "Hurufîlik”. Diyanet İslam Ansiklopedisi, XVIII, 408-412.

Anonim, Tefsir-i Ebced. Ankara Milli Kütüphane Yazmaları. 06 Mil Yz A 1688/5.

Bursalı İsmail Hakkı. Esrâru'l-Hurûf. Süleymaniye Kütüphanesi, Hacı Mahmud Ef. Yaz./2537, 22b-23a.

Ceylan, Ö. (1997). "Dinî-Tasavvufî Edebiyatımızla Divan Edebiyatındaki Harf Telakkilerinin Mukayesesi Üzerine Bir Deneme”. İlmî Araştırmalar Dergisi, 5, 141-152.

Demirli, E. (2008). “İbnü’l-Arabî'de Harf Sembolizmi”. İstanbul Üniversitesi İlahiyât Fakültesi Dergisi, 17, 223-236.

Hançerlioğlu, O. (1993). Düşünce Tarihi. İstanbul: Remzi Kitabevi.

Karabey, T. (1983). Türk Edebiyatında Tarih Düşürme. Yayınlanmamış Doktora Tezi. Erzurum: Atatürk Üniversitesi, Sosyal Bilimler Enstitüsü.

Küçük, H., \& Saraç, Y. R. (2009). “İbn Arabî’nin Kitâbü’l-Bâ Adlı Eseri”. Tasavvuf İlmî ve Akademik Araştırma Dergisi, 23 (İbnü'l-Arabî Özel Sayısı-2), 687-699.

Mercanlıgil, M. (1960). Ebced Hesabı. Ankara: Doğuş Matbaası.

Şenödeyici,Ö.(2009). “Hurûfiliği ÖnYargıdan Arındırmak Bağlamında Ferişteoğlu’nun Hidayetnâmesi’nin Tetkiki ve Neşri”. Divan Edebiyatı Araştırmalar Dergisi, 3, 87-146.

Şenödeyici, Ö. \& Akdağ, A. (2013). Tırnovalı Râşid Divançesi. Konya: Kömen Yayınları.

Usluer, F. (2009). Hurufilik İlk Elden Kaynaklarla Doğuşundan İtibaren. İstanbul: Kabalcı Yayınevi.

Yakıt, İ. (2010). Türk-İslâm Kültüründe Ebced Hesabı ve Tarih Düşürme. İstanbul: Ötüken Yayınları. 